\title{
INCREASING ROLE OF NEW SOCIAL MEDIA NETWORKING IN THE DEVELOPMENT OF GLOBALIZATION AND CHANGING GLOBAL PATTERNS
}

\author{
Dr. Huma Nisar \\ Assistant Professor \\ Department of Mass Communication \\ Federal Urdu University \\ Karachi - Pakistan \\ h.nisar@fuuast.edu.pk \\ Dr. Masroor Khanum \\ Assistant Professor \\ Department of Mass Communication \\ Federal Urdu University \\ Karachi - Pakistan \\ masroor.khanum@fuuast.edu.pk
}

\section{ABSTRACT}

The $21^{\text {st }}$ century is the era of technological advancement and unwanted natural and manmade incidents and disasters. The development of information technology opened new doors for everyone to achieve their desires and destinies without any boundaries which resulted in global progress and calamities at the same time. The world is at the peak of development and facing the most severe challenges together in the shape of COVID19, Delta Variant, and the same kind of other viruses with the highest rate of social connectivity. Social media networking, Online business, and shopping, virtual education, online medical facilities, and OTT entertainment increased globalization beyond the imagination of everyone. Social media networking sites played a very important part in every life today. No one can escape from its influence and hide their life and existence from others. People are connected beyond regional connotations and vocal on almost everything without any control. The research is intended to discuss and explain the role of social media in 


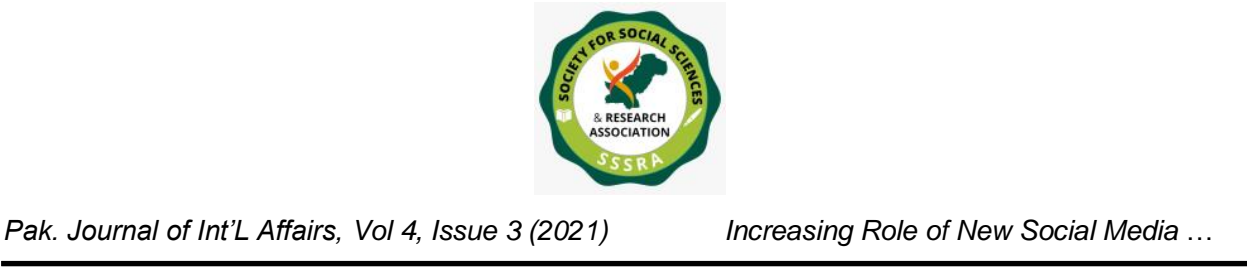

rising global connectivity and connecting people on digital platforms as well as their impact on daily life.

KEYWORDS: Global connectivity, Media, Internet, Social networking, COVID19, Virtual Education, International Organizations,

\section{INTRODUCTION}

Every nation has its customs and traditions, norms, and living styles which give them an individual identity to represent their nation in the world. Nations state system based on a distinct character of every nation. This nationalism concept was challenged by globalization after the end of WWII but at the beginning of the $21^{\text {st }}$-century nation-states and promoters of nationalism were defied by the outburst of social media and excessive use of the internet. The world is in a real sense change into a global village as Chen and Zhang (2010) said;

"The compression of time and space, due to the convergence of new media and globalization, has shrunk the world into a much smaller interactive field"(Chen \& Zhang, 2010).

Globalization initially began with economic means and later entre in other ways of life, social media enhance its role and engage people in a swift and sophisticated manner people now link around the world irrespective of differences and terrestrial limits. Interaction with each other today contains few seconds of sending and receiving messages. Facebook, Instagram, WhatsApp, Twitter, and other mediums transform national citizens into global. Global Socialization increases on one hand and the other hand people use it for learning and gathered knowledge of far countries without visiting the place. The key factors of social globalization are communication and interaction which shows how social media influence and create an impact on intercultural adaptation. COVID-19 (Corona Virus Infectious Disease-2019) came into our lives in December 2019. When people heard of lockdown in the Chinese industrial province Wuhan, no one was in the state of believing that it struck the whole world so hard and locked them in their homes. The people from north to south and from east to west the interaction was remain social media, online supply chains, and online business. Airlines, railways, auto vehicle transports were all closed people stuck in different places. From grocery to medicine, clothing to decoring, food to hygiene all available only through social mediums online sites. 


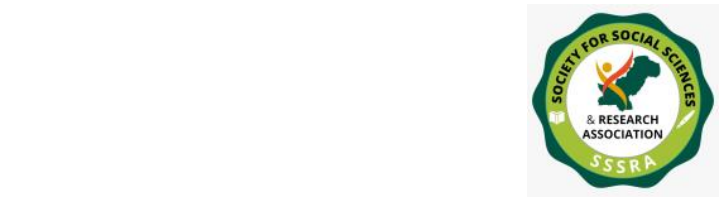

Pak. Journal of Int'L Affairs, Vol 4, Issue 3 (2021)

Increasing Role of New Social Media ...

The entire world joins together faces the same losses and mourns together for their loved ones. Social media proved their existence and globalize the world to the next level. The respective research is related to this advanced experience of life which today every individual experiences in their daily life. The research is intended to explain the corelation of globalization and social media, their significance, and the challenges of the new pandemic world of politics.

\section{GLOBALIZATION}

The specific term understands as a set of social developments that transform the existing national social state into globalism. 'Globalization' has been diversely used after WWII, generally in the press and literally in academics to describe a process, a condition, a system, a force, and an age (Steger, 2013: 30). According to Gidden; "Globalization is the intensification of worldwide social relations which link distant localities in such a way that local happenings are shaped by events occurring many miles away and vice versa" (Gidden, 2007). Whereas David Held defined it as "a process (or set of processes) which embodies a transformation in the spatial organization of social relations and transactions - assessed in terms of their extensity, intensity, velocity, and impactgenerating transcontinental or interregional flows and networks of activity, interaction, and the exercise of power"( Held \& McGrew, 2007).

Initially, it was used for economic purposes such as common provisions for the production, exchange, distribution, and consumption of goods and tangible services (Ifigeneia \& Dimitrios, 2018), later it was started to use as a policy for enforcing power in a societal domain particularly in the systematized exchange of force and inspection as well as the authorized conversion of these activities in diplomacy. At last, it was beginning to be utilized for culture transformation and in the field of communication. The outburst of the internet increased the speed of globalization and connecting people around the world on multiple grounds. The term trans-communication also became common everywhere. The new millennium introduced many ways of social transboundary communication in the shape of social mediums which very swiftly become part of global life. The globalization of media enables the sharing of self-made content globally through many social media sites (Liebes \&Katz 1990: 106). It stimulates different cultures through the circulation of information. The inclusion of social media in economic and social resources caressing substantial impact on globalization (Curran 2002: 218).

\section{NEW SOCIAL MEDIA NETWORKING}




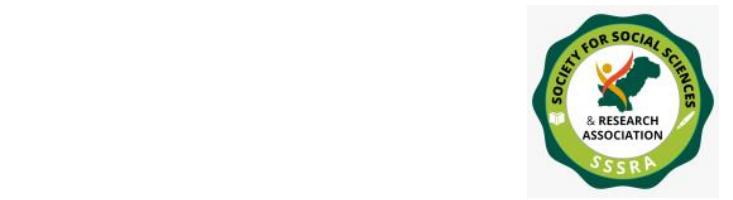

The term Social media has become common in all parts of the world which is a collection of websites and applications that focuses on community-based communication, input, interaction, and content-sharing (https://whatis.techtarget.com/definition/social-media). It brings people together with different backgrounds and encourages interaction. Boyd and Ellision (2007) define social networking sites as

\begin{abstract}
"Web-based services that allow individuals to (1) construct a public or semi-public profile within a bounded system, (2) articulate a list of other users with whom they share a connection, and (3) view and traverse their list of connections and those made by others within the system" (Boyd and Ellision (2007).
\end{abstract}

Since 2011, social media has reached almost every corner of the world and social mediabased business was increasing with every passing day. The advancement of multimediacapable mobile devices empowered more people to enter a world of social media (Croucher, 4(4) 2011: 259-264). The most prevalent social networking sites are Facebook, YouTube, Twitter, Instagram, WhatsApp, Messenger, Tiktok, WeChat, Snapchat, etc.

- Facebook: It was created by Mark Zuckerberg in 2004, with the idea to provide mutual ground for those having distinctive backgrounds and multinational culture. A platform for people of the world to interact and erase the boundaries between them. FaceBook brought the revolution in the world and very swiftly people join this site and in few years it becomes the largest user site and officially changes the scenario of globalization with 2.7 billion users. This social networking among several nations augments common lives beyond territorial distances.

- Youtube: The second famous networking site is YouTube which began in 2005 as a video-sharing website that "permits everyone to socialize globally by watching and sharing audiovisual content" (Georgetown University, 2010). This site provides the opportunity for common men to comment on videos and contribute to debates and sessions. Today everyone has used YouTube, and this "became a driving force for change around the world" (Ostrow, 2010). YouTube has 02 Billion users in 2021 and is holding the place of second most famous networking site after Facebook (https://www.globalmediainsight.com/blog/youtube-users-statistics/). It has multiple uses such as; companies use it to advertise their businesses to promote in the world and reach to new markets. People connected with worldwide actions, entertainment uploading 


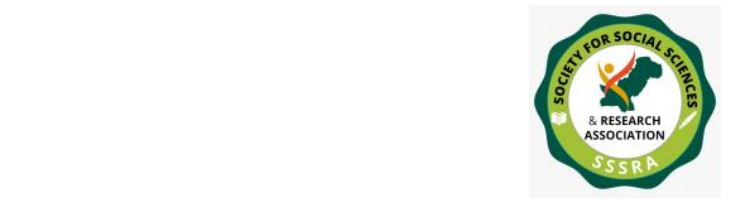

Pak. Journal of Int'L Affairs, Vol 4, Issue 3 (2021)

Increasing Role of New Social Media ...

videos reaching all continents and nation's stars become global stars, similarly, all information is now on a one-click with analysis and future consequences. Some contents prompt controversy and it can get global reactions and sentiments on the subject, which is sometimes against social norms and limits.

- Whatsapp: WhatsApp is a free messaging, voice call app, that can host video chats on both desktop and mobile devices. It was started in 2009 and few years has become one of the most famous US text and voice messaging app. The service is owned by Facebook. (Dove \& Beaton, $21^{\text {st }}$ March 2021). It works on numerous phone and computer systems, helping with messaging. Very swiftly WhatsApp becomes routine in more than 180 countries and also includes in the top 10 sites globally. In the beginning, the site which was formulated for communication among friends and family now turned into business communication. It conducted video conferencing, business owners properly framed their professional profiles to share updates and offer customer support to the customers. It also uses for educational information as well as for the social and civic union.

- Twitter: Twitter is a form of networking where people can interconnect information with minimum words it is also called microblogging. People "talk about their daily activities and to seek or share information" on that site (Java et al., 2007). Twitter was created in 2006 to transmit important information using fewer words like text messages and opinions to users.

"The platform was inspired by creator Tim Dorsey's introduction of an SMS-based concept that allowed members of his then-company, Odeo, to keep tabs on one another. The name 'Twitter'...is used to describe a short burst of inconsequential information” (Georgetown University, 2010).

It has 3.2 million users today. This site has more credibility than other social networking sites because generally, people follow only those on this site in which they feel connected and acknowledged for the actions and sentiments of others. Twitter is also known as an intellectual site because it provides the opportunity to directly communicate with important people like statesmen, celebrities, sportspersons, politicians, and others.

- Instagram: Instagram is another innovative social media app which changes the mindset of people, the idea rapidly becomes a sensation. It was created by Kevin Systrom and Mike Krieger in 2010 by Facebook (https://www.mobileappdaily.com/best-socialmedia-apps). It has now more than 2 billion users which are increases every passing day. 


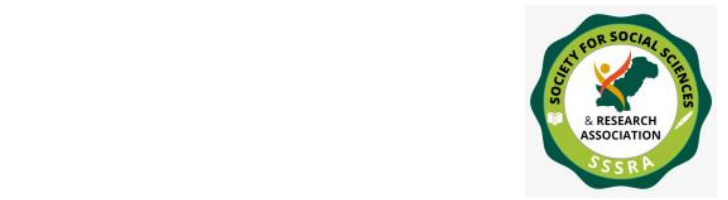

Every other day, it acquaints with advanced features for its users and engages them more and more. Instagram allows everyone to share an inclusive array of videos, live videos, photos, and stories. It has also launched IGTV for long videos. Anyone can promote their product, by creating a professional profile and reach to the global arena. It provides every kind of perspective on posts, views, likes, and profiles.

- $\quad$ Snap Chat: It is the US multimedia instant messaging app and service developed by Snap Inc (US camera and social media company). It was founded by Evan Spiegel, Bobby Murphy, and Reggie Brown in 2011(https://en.wikipedia.org/wiki/Snap_Inc). Snapchat is one of the best fun apps which has enchanted millions of people by now. On this app, the users can send a picture or a short video as a message which automatically disappears after a few seconds. It was one of the newest apps which made the 'stories' widespread. The popularity of Instagram has affected Snapchat's growth and marketers' interest in using it as a marketing and advertising platform.

Above mentioned networking sides are few among many which are more popular but other networking sites also gained popularity like Linkedin, Tinder, We Chat, Tik Tok, Reddit, Pinterest, Facebook messenger, Viber, Line, QQ, Sina Weibo, etc. Globalization and their relationship are as obvious as the relation of finger and nail, both are joint and cannot be parted.

\section{USE Of SOCIAL MEDIA IN GLOBAL E-COMMERCE}

During the last five years, the phenomenon of online business and shopping sites gets fame along with social media networking, and speed up the growth of globalization. People of the $20^{\text {th }}$ century would never believe that after only one decade the facilities reaching par excellence and everything they need to reach their doorstep globally without any distinction of East or West is become the reality. The online shopping and delivering idea was initiated in 1979 by Micheal Aldrich in the United Kingdom when he connecting television to the computer via telephone line and invented a system that later become the foundation for online shopping. Whereas in 1982 the Boston computer Exchange was launched and become the first e-commerce company that provides an online marketplace for buying and selling used computers. In 1995 Jeff Bezos launched Amazon.com an online book retailing international company within 30 days of shipping for 45 countries. In 1998 by the name of PayPal an e-commerce payment system was introduced by an American multinational financial technology company. In 2005 online business has reached another level when Amazon prime was offered free shipping and 


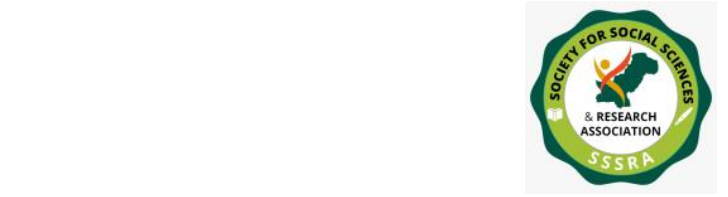

discounts on annual subscriptions. Thus every year of the new millennium presented innovations for consumers with unimaginable ease and sophistication.

Apart from business and shopping, online service for food delivery was initially started in 1994 by Pizza Hut in the USA, and by late 2000, $40 \%$ of Pizza was delivered online in the country. The online food delivery facility was very quickly adopted by other parts of the world and people start ordering their food on given websites and enjoy it without wait and disturbance.

In 2016, social media arrive in the business arena, and Facebook introduced a marketplace with

shopping within their capacity. Hence people of third world countries have also entered the scene and many local online websites start competing with global brands on big names. Apps like Food Panda, DARAZ, Market.com, and many others have also become part of life. Gradually the local big brands also enter the business and all kinds of stuff are now available online with free and paid shipment.

\section{USE OF SOCIAL MEDIA NETWORKING DURING COVID19}

The upsurge of the COVID-19 pandemic in 2019 at Wuhan, gradually reach every part of the world and people faced severe lockdown. The world was stuck in their houses, all kinds of work were shifted at home or close for the time being. People had no other option accept using a cell phone, watch television or spend time on social media not only for work but also for passing time. During that period the amount of using Facebook, YouTube, Instagram, Twitter, or WhatsApp increases with a large proportion. These social networking sites are used for rapid and easy awareness of health and safety-related information against such infectious viruses as well as their spread speed and for personal precautions to prevent the virus.

Education all over the world is also shifted into online education platforms. Governments of several countries shut the face-to-face physical classes for sake of holding the spread of COVID19 and instructed all educational institutions to conduct online mediums for learning. The emergency shifting from face-to-face learning to online teaching was a very hard task not only for developing and under the developed countries where basic requirements of virtual learning were very minimum but it was also not easy for developed nations either. However, it became possible due to online social mediums who provided immediate solutions with multiple options like WhatsApp video conferencing, Zoom meetings, Google class, etc. Such platforms were not new and they were used for virtual methods of teaching but during the lockdown period, the amount of usage was 


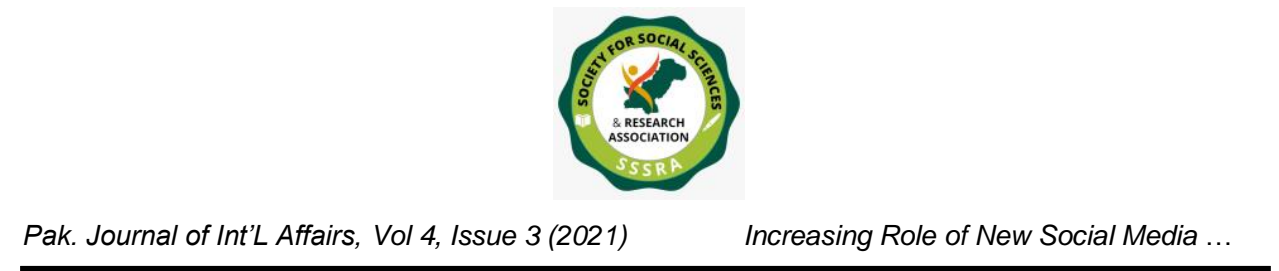

increased magnanimously which was only possible because of internet and social media networking.

The lockdown rise the online shopping business because there was no other option left for getting essential during a pandemic outbreak. From food to clothing everything from everywhere is accessible only by internet means. This situation opened options for those jobless employees who lost their jobs due to extensive closure by their regimes.

The entertainment sites also received more users during Covid time. The usual media channels provided regular entertainment which after a while bored them, on the other hand, every kind of sports was also abandoned therefore sports channels were also had no other option than repeat previous shows. Sites like TikTok, Instagram, and Snapchat reach the masses due to their creativity and excitement of doing something by themselves. Cinemas were also closed so, movies were also shifted on the OTT (Over the top) platform and Netflix, Apple, Disney Hotstar kind web channels become alternative options for movie lovers. People from every corner of the world become the audience of such sites and become part of a global culture where boundaries can not stop them to watch anything.

\section{CONCLUSION}

Globalization and technology have joined together in social media and made time and space immaterial as well as ensure that people globally can meet and discuss every kind of issue without any restriction (Morris 2002: 283). Social media provided everyone their loudspeaker thus people nowadays have their opinion on everything also vocal on everything. Globalization reaches the place where it never reaches before. People are in an actual sense become global citizens. Social media joined the whole world together, nothing is beyond the reach today. From politics to medical information everything comes on just one click away not only for the developed world but also in developing and underdeveloped countries.

China and India are the largest users of Social media networking sites both are belong to developing nations. Incidents of George Floyd happened in the USA similarly affected other regions and voices came across the globe that "Black Lives Matter" showed how the world connected today. Afghanistan's change of Government from the US sponsored Asharaf Ghani to Taliban within few seconds reached everywhere. Christiano Ronaldo is the Portuguese footballer who has the highest Insta and Twitter followers, more than the Portugues, Indians, and other nations followed him. 
COVID 19 brought people closer than ever before. The need for Oxygen for Corona Patients in India is fulfilled by Saudi Arabia without thinking of religion or any other discrimination. WHO took charge of every region and make sure to provide all basic medical needs everywhere. Deaths in the USA, Italy, Spain, and India, or any other place due to COVID have the same effect. This kind of togetherness is only possible due to the close relation of globalization with social media networking sites.

The respective research concluded that social media networking has become an essential part of globalization and no one can escape from them. By hook or by crook everyone uses some kind of social medium and is informed about the world. In the next few years, more new networking sites will introduce and the usage of social mediums will more increase. It is now Jinny out of the bottle and it will be difficult to close it again thus, now it can only control by smart use of it with getting more and more benefits for themselves. 


\section{References}

Boyd, D.M., Ellison, N.B. (2007) Social network sites: Definition, history, and scholarship, Journal of Computer-Mediated Communication, 13(1).

Best Social Media Apps in 2021. https://www.mobileappdaily.com/best-social-mediaapps (Retrieved 11Sep 2021)

Chen, G. M., \& Zhang, K. (2010) New media and cultural identity in the global society. In R. Taiwo (Ed.), Handbook of Research on Discourse Behavior and Digital Communication: Language Structures and Social Interaction (pp. 801-815). Hershey, PA: Idea Group Inc.

Croucher, S. (2011) 'Social Networking and Cultural Adaptation: A Theoretical Model', Journal of International and Intercultural Communication, vol. 4, (4) pp. 259-264.

Curran, J. D. (2002) Media and Power, New York: Academic Press

Dove, Jackie \& Beaton, Paula (21 ${ }^{\text {st }}$ March 2021) What is Whats App? https://www.digitaltrends.com/mobile/what-is-whatsapp/

Gidden, Anthony (2007) Europe in a Global age, USA: Willey Blackwell

Held, David \& McGrew, Anthony (2007) Globalization Theory, USA: Polity Press

https://en.wikipedia.org/wiki/Snap_Inc

https://www.globalmediainsight.com/blog/youtube-users-statistics/

Ifigeneia, Mylona \& Dimitrios, Amanatidis (2018) Globalization, Social Media and Public Relations: A Necessary Relationship for the Future? https://knepublishing.com/index.php/KnE-Social/article/view/3546/7438 (Retrieved: 11sep 2021)

Liebes, T. \& Katz, E. (1990) The Export of Meaning: Cross-Cultural Readings of Dallas, New York: Oxford University Press

Sawyer, Rebecca (2011) "The Impact of New Social Media on Intercultural Adaptation" Senior Honors Projects. Paper 242 http://digitalcommons.uri.edu/srhonorsprog/ 
Steger, Manfred B. (2013) A very Short Introduction of Globalization, UK: Oxford University Press 